\title{
INFLUENTIAL FACTORS IN SURFACE WATER QUALITY IN CATCHMENTS WITHIN THE PAMPA BIOME WITH DIFFERENT LAND USE ${ }^{1}$
}

\begin{abstract}
Mirian Lago Valente ${ }^{2}$, Jussara Cabral Cruz ${ }^{3}$, Carine Baggiotto ${ }^{4}$ e Catarine Barcellos Consensa ${ }^{2}$
ABSTRACT - The aim of this study was to identify, by multivariate statistical technique, the physic, chemical and biological variables that best characterize the quality of surface waters in two small rural catchments with different land uses (eucalyptus silviculture (SC) vs. pasture and extensive livestock (LC)) located in Rosário do Sul, RS - Brazil. Monitoring was conducted during the months of August 2011 to August 2012 and the following parameters were analyzed: $\mathrm{Ca}^{2+}, \mathrm{Mg}^{2+}, \mathrm{K}^{+}, \mathrm{SO}_{4}^{2-}, \mathrm{Cl}^{-}, \mathrm{pH}$, electrical conductivity, turbidity, alkalinity, suspended and dissolved solids, biochemical oxygen demand, total coliforms, Escherichia coli and temperature, flow and rainfall. Through the use of FA/PCA, it was found that the model best fit to express water quality of in LC that was composed of five factors which account for $83.5 \%$ of the total variance, while for SC, four factors accounted for $85.12 \%$ of the variance. In LC, the five main factors were, respectively, soluble salts, diffuse pollution, solid, and both anthropogenic and organic factors. In SC, the four factors were namely: soluble salts, mineral, nutritional and diffuse pollution factors. The results of this study showed that by replacing the traditional soil usage (pasture and livestock) with planted forest, diffuse pollution was attenuated but, however, it did not result in major changes in the physical-chemical and biological characteristics of the water. Another point to note is that factorial analysis did not result in a large reduction in the number of variables, once the best model fit occurred with the addition of 15 of 18 analyzed variables (LC) and 17 of 18 analyzed variables (SC).
\end{abstract}

Keywords: Multivariate analysis; Water resources; Silviculture.

\section{FATORES INFLUENTES NA QUALIDADE DAS AGUAS SUPERFICIAIS EM BACIAS HIDROGRAFICAS INSERIDAS NO BIOMA PAMPA COM DIFERENTES USOS DO SOLO}

\begin{abstract}
RESUMO - O objetivo deste estudo foi identificar, por meio da técnica estatística multivariada, os fatores que melhor caracterizam a qualidade das águas superficiais em duas bacias hidrográficas rurais com diferentes usos do solo (silvicultura do eucalipto (BE) e campo antropizado com pecuária extensiva (BC)), localizadas no Município de Rosário do Sul, RS - Brasil. O monitoramento dos parâmetros de qualidade da água foi realizado entre os meses de agosto de 2011 e agosto de 2012, com as análises de: $\mathrm{Ca}^{2+}, \mathrm{Mg}^{2+}, \mathrm{K}^{+}, \mathrm{SO}_{4}^{2-}, \mathrm{Cl}^{-}$ , pH, condutividade elétrica, turbidez, alcalinidade, sólidos suspensos, dissolvidos e totais, demanda bioquímica de oxigênio, coliformes totais, Escherichia coli, temperatura, vazão e precipitação pluvial. Por meio da AF/ $A C P$, identificou-se que o melhor modelo de ajuste para expressar a qualidade das águas na BCfoi aquele composto por cinco fatores, explicando $83,5 \%$ da variância total, enquanto que na BE quatro fatores explicaram $85,12 \%$ da variância. Na BC, os cinco fatores foram denominados, respectivamente, sais solúveis, poluição difusa, sólidos, antrópico e orgânico. Já na BE os quatro fatores foram denominados como sais solúvel, mineral, nutricional e com poluição difusa. Os resultados permitiram concluir que a substituição do uso tradicional do solo com campo e pecuária extensiva por floresta plantada atenuou a poluição difusa na área e, de modo
\end{abstract}

\footnotetext{
${ }^{1}$ Recebido em 14.08.2014 aceito para publicação em 12.08.2015.

${ }^{2}$ Universidade Federal de Santa Maria, Programa de Pós-Graduação em Engenharia Florestal, Santa Maria, RS - Brasil. E-mail: <mirian_sm@yahoo.com.br>e <catarineconsensa@gmail.com>.

${ }^{3}$ Universidade Federal de Santa Maria, Centro de Tecnologia, Departamento de Engenharia Sanitária e Ambiental, Santa Maria, RS - Brasil. E-mail: <jussaracruz@gmail.com>.

${ }^{4}$ Universidade Federal de Santa Maria, Programa de Pós-Graduação em Engenharia Sanitária e Ambiental, Santa Maria Brasil. E-mail: <carine.bg@hotmail.com>.
} 
geral, não implicou grandes alterações nas características físico-químicas e biológicas da água. Outro ponto observado foi que, neste estudo, a análise fatorial não resultou em grande redução no número de variáveis, uma vez que o melhor ajuste do modelo ocorreu com a inclusão de 15 das 18 variáveis analisadas (BC) e de 17 das 18 variáveis analisadas (BE).

Palavras-chave: Análise multivariada; Recursos hídricos; Silvicultura.

\section{INTRODUCTION}

Land use management and alteration at catchment scale, results in different responses within qualitative and quantitative water properties and thus, proper planning is essential because a poorly executed project can trigger severe consequences in the processes that guide the environmental health of water bodies.

In the southern half of the Rio Grande do Sul Brazil, replacing the traditional use of extensive cattle ranching with eucalyptus silviculture raised many questions regarding possible changes in soil characteristics as well as possible effects on water resources. Water quality monitoring parameters is one of the water resources management tools, as stated in the Federal Law 9433 (BRASIL, 1997), which is essential for targeting actions that promote protection and improvement of water sources due to changes in land use.

As a result, there has been an increase in the number of water monitoring programs in order to investigate the effects of land use on the physical-chemical and biological characteristics of water. Frequently, the analysis and interpretation of databases from biomonitoring admits some instability (BURIN, 2011) situation expected by the researcher and justified by the nature and diversity of variables involved. Liao et al. (2008) points out that these data are very complex due to the range of information and the different units scales involved.

Given the difficulty of interpretation of the biomonitoring data, a multivariate statistical technique has been widely used in the analysis and interpretation of various studies, for example (MELO; HEPP, 2008; SALGADO et al., 2011; GARDIMAN JUNIOR, 2012; GATICA et al., 2012; GUEDES et al., 2012; WANG et al., 2012).

Among the methods of multivariate analysis, the one most often applied has been the factorial analysis (FA) with the method of Principal Component Analysis (PCA). Factorial analysis includes a set of statistical techniques that aims to reduce the number of initial variables without a significant loss of information contained in the original data (HAIR et al., 2005), whereas, with the principal component analysis it's possible to isolate and select the variables which impact each factor the most, thus determining which ones should be monitored, and by doing so reducing costs in water quality monitoring (BRITO et al., 2006),

This study aims identify by means of multivariate statistical technique the main factors that best characterize the quality of surface water in two rural catchments with different land uses (eucalyptus silviculture and pasture with extensive livestock) located in Rosário do Sul, RS - Brazil.

\section{MATERIALAND METHODS}

\subsection{Location and characterization of the investigated areas}

The study took place in two catchments located in Rosario do Sul, RS - Brazil. One of the experimental areas owned by Stora Enso S/A company, features eucalyptus silviculture activity along with the protected areas (area of permanent preservation and legal reserve) (SC), as shown in Figure 1a. The other catchment (Figure 1b), private ownership, features pastures and extensive livestock (LC). The selection of areas was based on the paired catchment approach, regarding soil, landscape and rainfall characteristics, they differ, however, in land use. The areas are $13 \mathrm{~km}$ away from each other in a straight vertical (north-south) line, and altitudes of 153 and $133 \mathrm{~m}$ for the SC and LC, respectively.

The climate, according to Köppen climate classification, is classified as $\mathrm{Cfa}$, humid subtropical with hot summer (ALVARES et al., 2013). In accordance with the IUSS (2014), the soils of areas was classified as Abruptic Alisols (Alumic, Differentic) originated from siltstone and sandstone in transition with Planosols from the Central Depression (STRECK et al., 2008).

The SC comprehends a total area of 95 ha with more than half of that ( 48.85 ha) destined for eucalyptus (Eucalyptus urograndis $-91.4 \%$ and Eucalyptus grandis and Eucalyptus dunnii) farming, the wood destined 

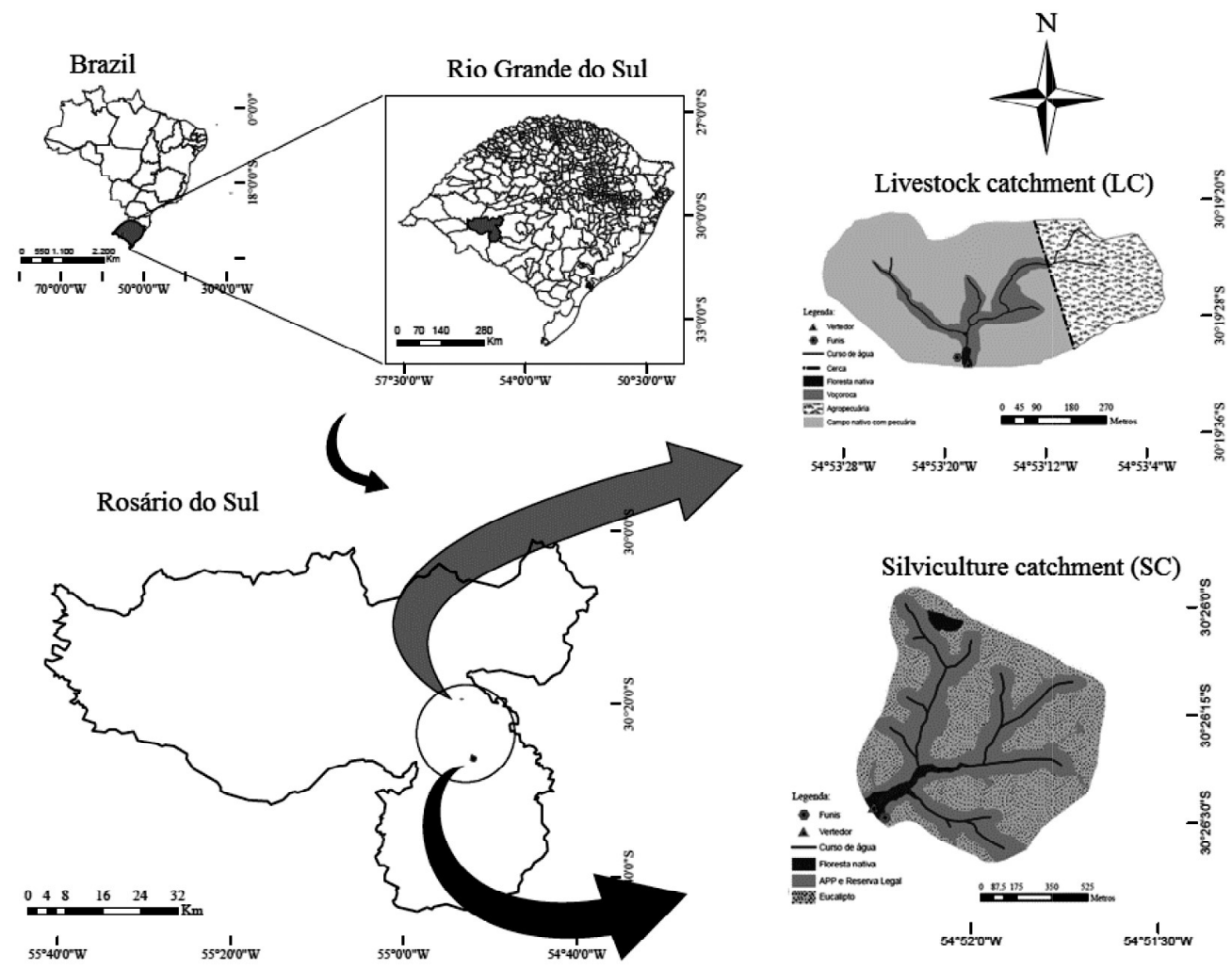

Figure 1 - Land use maps of the investigated catchment, (A) with eucalyptus silviculture and environmental protection areas (SC) and (B) with pasture and extensive livestock farming (LC).

Figura 1 - Mapas de uso do solo das pequenas bacias hidrográficas investigadas, sendo (A) com silvicultura do eucalipto em conjunto com as áreas de proteção ambiental (SC) e (B) com campo e pecuária extensiva (LC).

for pulp production. The remaining area (46.15 ha) corresponds to the areas of environmental protection, without the presence of livestock, a percentage higher than what is recommended by the Brazilian legislation (20\%), according to Federal Law No. 12,651, of May 25, 2012 (BRASIL, 2012).

The LC comprises a catchment area of 21 ha, with the land use most often found within the Pampa biome, extensive livestock and pasture, the drainage network of the catchment features riparian protection only in the area of the river mouth wherein the cattle have access to the site.

\subsection{Instrumentalization and sampling}

Each catchment was equipped with a triangular $90^{\circ}$ spillway (built at the river mouth) with thin wall made from a 3-mm sheet of galvanized steel, according to the Technical Standard No. 2004-CPRH and a 80 $\mathrm{cm}$ deep well reassuring $60 \mathrm{~cm}$ x $60 \mathrm{~cm}$ x $80 \mathrm{~cm}$, where pressure transducers were installed to record time of water blade to calculate the flow. The total daily rainfall was measured by a rain gauge model "Ville de Paris" from HIDROMEC ${ }^{\circledR}$ with a water capture area of 400 $\mathrm{cm}^{2}$, placed between the monitored catchments, where a technician was present for collection and quantification. For better assessment of rainfall data, adjacent to the study area, were installed four rain gauges in a clearing where rainfall was quantified with the aid of a measuring cylinder during surface water sampling campaigns.

The sampling procedure as well as the conservation of surface water samples followed the precepts established by the Norm 9898 June 1987 (ABNT, 1987). Every two weeks between the months of August 2011 to August 2012, a sample of water was collected at the monitoring station (river mouth) of each catchment, resulting in 20 sampling campaigns.

Revista Árvore, Viçosa-MG, v.39, n.6, p.1135-1145, 2015 
Samples were taken during the morning, avoiding a period of over 2 hours between sample collections. Before each collection, the polyethylene containers used for packaging the samples were acclimated to the water from the stream at least three times before the final collection. Samples stored in 0.5-liter containers were transported to the Forest Ecology Laboratory (LABEFLO) of the Department of Forest Science at UFSM for further analysis of cations and anions, while the samples stored in 5-liter containers were shipped to the Laboratory of Engineering and Environment (LEMA) of UFSM Technology Center for the analysis of other physical, chemical and biological parameters.

\subsection{Physical-chemical and biological water analysis}

The analysis followed the method described by APHA (1998). The ion analysis had the pretreatment simple filtration $(0.45 \mu \mathrm{m}$ pore $)$ and were subsequently analyzed by ion chromatography (Metrohm 861 Advanced Compact IC) the anions ( $\mathrm{SO}_{4}^{2-}$ and $\left.\mathrm{Cl}^{-}\right)$as anions columns and the cations $\left(\mathrm{K}^{+}, \mathrm{Ca}^{2+}\right.$ and $\left.\mathrm{Mg}^{2+}\right)$ as the cation columns. The other parameters followed the methodologies: 2540 B for total solids (TS), 2540 C for dissolved solids (DS), $2540 \mathrm{D}$ for suspended solids (SS), $2130 \mathrm{~B}$ for turbidity, 2320 B for alkalinity, Winckler for Biochemical Oxygen Demand $\left(\mathrm{DBO}_{5.20}\right)$, Idexx-Colilert ${ }^{\circledR}$ for the analysis of total coliforms (TC) and Escherichia coli (E. coli). The $\mathrm{pH}$ and electrical conductivity (EC) were analyzed using bench-top Combined Conductivity/pH Meter, brand name WTW, and in situ, was analyzed by thermometry temperature.

\subsection{Multivariate Statistical Analysis}

To perform the factorial analysis by the method of the main components (FA/PCA), first, there was the processing of raw data, such as correction of failures and outliers. The standardization of data was also performed, as this procedure is recommended for biomonitoring data that include the characterization of water quality (CAMPELLO et al., 2005; MELO; HEPP, 2008; GARDIMAN JUNIOR, 2012; GUEDES et al., 2012) because of the different metrics scales among the analyzed parameters.

From the authors' perspective, standardization is the first step before carring out the multivariate analysis, according to equation 1 .

Revista Árvore, Viçosa-MG, v.39, n.6, p.1135-1145, 2015

$$
\mathrm{Z}=\frac{\mathrm{X}-\mu}{\sigma}
$$

Where: " $Z$ " is the standard variable; " $\mathrm{X}$ " is the observed variable; " $\mu$ " is the average of the variable; "ó" standard variable deviation. Then the FA/PCA analysis, which consists of three steps, was applied: the first step is to transform the original data into a correlation matrix [R] ( $\mathrm{p} \times \mathrm{p}$ ), for $\mathrm{p}$ equals the number of water quality parameters analyzed in this study; the second has to do with the extraction of the common factors and, finally, the Varimax orthogonal rotation of the axles in regard to common factors (main components) for ease of interpretation.

After the defining correlation matrix, an inspection of the parameters was performed in order to identify the most specific variables, since the purpose of the FA/PCA consists in obtaining components that justify the correlations. Note that the statistical analyzes were performed by study area, and afterwards, data from the different catchments was compared.

The overall consistency of the data was performed by the Kaiser Meyer Olkin adequacy test (KMO). According to Pereira (2001), values close to 1 indicate a good application of the model. The analysis was performed using the Statistical Package for Social Sciences 17.0 software (SPSS) and the selection of the number of extracted components followed the precepts presented by Norusis (1990) where only the components with variance higher than one are considered.

\section{RESULTS}

The Kaiser Meyer Olkin (KMO) test of adequacy showed an index of 0.59 in LC which indicates adequacy of the data for the FA/PCA (HAIR et al., 2005; PEREIRA, 2001). The variables that did not contribute to the adequacy were: sulfate, chloride and total solids. For $\mathrm{SC}$, the KMO index amounted to 0.62 indicating a good fit of the data for FA/PCA where only the parameter "total solids" did not contribute to the test.

Table 1 presents the mean values and standard deviations for each parameter analyzed for the LC and SC study areas.

Factors of rotated components (FA) by the Varimax method with eigenvalues greater than 1 , the factorial loads, eigenvalues, the commonalities, unit and cumulative variance for LC and SC are shown in Tables 2 and 3, respectively. 
Table 1 - Gross, average and standard deviation values of the physical, chemical and biological water for the eucalyptus silviculture catchment (SC) and for the pastures and extensive livestock farming catchment (LC).

Table 1 - Valores brutos, médios e desvio padrão dos parâmetros físicos, químicos e biológicos da água para a bacia com atividade de silvicultura do eucalipto (SC)) e com campo e pecuária extensiva (LC).

\begin{tabular}{|c|c|c|c|c|}
\hline \multirow{2}{*}{ Variables } & \multicolumn{2}{|c|}{ Silviculture Catchment } & \multicolumn{2}{|c|}{ Pasture and Livestock Catchment } \\
\hline & Means & Standard Deviation & Means & Standard Deviation \\
\hline $\mathrm{pH}$ & 7.24 & 0.21 & 6.22 & 0.28 \\
\hline $\mathrm{EC}\left(\mu \mathrm{S} \mathrm{cm}^{-1}\right)$ & 270.70 & 124.20 & 39.68 & 12.84 \\
\hline Turbidity (UNT) & 13.39 & 12.69 & 12.77 & 12.14 \\
\hline Total Col. NMP/100 ml & 1253.98 & 1346.90 & 5952.84 & 8209.57 \\
\hline Escherichia coli $\mathrm{NMP} / 100 \mathrm{ml}$ & 611.79 & 1592.88 & 3734.14 & 10858.30 \\
\hline $\mathrm{BOD}_{5.20}\left(\mathrm{mg} \mathrm{L}^{-1}\right)$ & 4.53 & 4.73 & 2.32 & 1.56 \\
\hline $\mathrm{SS}\left(\mathrm{mg} \mathrm{L}^{-1}\right)$ & 9.66 & 9.31 & 10.31 & 11.55 \\
\hline $\mathrm{DS}\left(\mathrm{mg} \mathrm{L}^{-1}\right)$ & 189.09 & 69.13 & 55.66 & 42.34 \\
\hline $\mathrm{TS}\left(\mathrm{mg} \mathrm{L}^{-1}\right)$ & 198.75 & 70.84 & 63.25 & 49.39 \\
\hline Alc. $\left(\mathrm{mg} \mathrm{L}^{-1}\right)$ & 136.60 & 63.76 & 13.62 & 7.13 \\
\hline $\mathrm{Cl}^{-}$ & 2.44 & 1.03 & 2.53 & 1.78 \\
\hline $\mathrm{SO}_{4}^{-}$ & 0.99 & 0.89 & 0.28 & 0.21 \\
\hline $\mathrm{K}^{+}$ & 1.76 & 0.43 & 2.82 & 1.33 \\
\hline $\mathrm{Mg}^{2+}$ & 5.20 & 2.03 & 1.37 & 0.49 \\
\hline $\mathrm{Ca}^{2+}$ & 32.74 & 16.05 & 2.17 & 0.78 \\
\hline Temp. ${ }^{\circ} \mathrm{C}$ & 17.02 & 5.82 & 17.60 & 5.17 \\
\hline Flow $\left(\mathrm{L} \mathrm{s}^{-1}\right)$ & 3.33 & 5.78 & 1.00 & 1.56 \\
\hline *Prec. $(\mathrm{mm})$ & 9.30 & 19.79 & 8.67 & 15.50 \\
\hline
\end{tabular}

Note: $\mathrm{EC}\left(\mu \mathrm{S} \mathrm{cm}^{-1}\right)$ - electrical condutivity; TC (NMP/100ml) - total coliforms; $\mathrm{BOD}_{520}\left(\mathrm{mg} \mathrm{L}^{-1}\right)$ - Biochemical oxigen demand; $\mathrm{SS}$ $\left(\mathrm{mg} \mathrm{L}^{-1}\right)$ - suspended solids; DS $\left(\mathrm{mg} \mathrm{L}^{-1}\right)$ - dissolved solids; TS $\left(\mathrm{mg} \mathrm{L}^{-1}\right)$ - total solids; Alc. $\left(\mathrm{mg} \mathrm{L}^{-1} \mathrm{CaCO}_{3}\right)-$ alcalinity; $\mathrm{Cl}^{-}\left(\mathrm{mg} \mathrm{L}^{-1}\right)$ - chloride; Sulf $\left(\mathrm{mg} \mathrm{L}^{-1}\right)$ - sulfate; $\mathrm{K}^{+}\left(\mathrm{mg} \mathrm{L}^{-1}\right)$ - potassium; $\mathrm{Mg}^{2+}\left(\mathrm{mg} \mathrm{L}^{-1}\right)$ - magnesium; $\mathrm{Ca}^{2+}\left(\mathrm{mg} \mathrm{L}^{-1}\right)-$ calcium; Temp $\left({ }^{\circ} \mathrm{C}\right)$ - temperature; *Prec. $(\mathrm{mm})$ - precipitation (rainfall) up to $48 \mathrm{~h}$ prior to sampling.

In determining the main components, the catchment with pasture and extensive livestock, presented five eigenvalues greater than 1 , which contain $83.5 \%$ of the total variance observed in the data (Table 2). After the rotation of the components by the Varimax method, the loads referred to as "factor" greater than 0.60 were considered for interpretation. Thus, the first factor is "soluble salts" which accounts for $39.31 \%$ of the variance; The second factor is "diffuse pollution" which explains $15.33 \%$; the third is the "solids" factor from the drag of solid particles by runoff and represents $11.93 \%$ of the variance; the fourth factor is "anthropic" which represents the extensive livestock farming activity, with $9.39 \%$; and the fifth, is the "organic" factor was represented by the dissolved solids variable with $7.61 \%$ of the variance.

For the eucalyptus silviculture catchment, the FA/ PAC resulted in four factors with eigenvalues greater than 1.0 , which represent $85.12 \%$ of the total variance observed (Table 2). The first relevant factor is "soluble salts" which explains $51.42 \%$ of the variance; the second, factor "minerals" explains $15.61 \%$; the third, "nutrition" $11.45 \%$ and the fourth factor "diffuse pollution" represents $6.63 \%$ of the variance.

\section{DISCUSSION}

In LC (Table 2), VF1 (first rotational element) showed high positive loading for electrical conductivity, alkalinity, magnesium and calcium $(>0.75)$. Similarly for VF1-EC (Table 3 ), loads higher than 0.75 were observed for the parameters $\mathrm{pH}$, turbidity, dissolved solids and flow, in addition to the previously mentioned variables.

The similarity among the factors of the study areas points to a common origin of the minerals with higher loading, such as the rocks weathered of that originated the soil. Siltstone and sandstone make up the rock formation source in the study areas, a composition which may have contributed to an increased susceptibility to erosion and to greater decomposition of crop residues, which is why it requires more intense management and soil conservation practices than areas with ultisols from basalt (STRECK et al., 2008), which can contribute to the increase of certain elements.

Thus, both factors (VF1 - LC, SC) can be referred to as "soluble salts" factors because they express a greater association with variables indicative of

Revista Árvore, Viçosa-MG, v.39, n.6, p.1135-1145, 2015 
enrichment by soluble ions due to the composition of the soil in the area, such as $\mathrm{Ca}^{2+}$ and $\mathrm{Mg}^{2+}$ (LIMA; ZAKIA, 2006), alkalinity and electrical conductivity (CÂMARA et al., 2006; CETESB, 2009). Lauermann
(2007) states that both $\mathrm{Ca}^{2+}$ and $\mathrm{Mg}^{2+}$ contribute to the increase in $\mathrm{EC}$, it has also been observed by the authors Andrade et al. (2007a, b), Gardiman Junior (2012) and Salgado et al. (2011) in water quality studies.

Table 2 - Factors of rotated components (VF) by Varimax algorithm, associated commonalities, eigenvalues, unitary and culumative variance of the physical, chemical and biological variables significant for the pasture and extensive livestock farming catchment (LC).

Tabela 2 - Fatores das componentes rotacionadas (VF) pelo algoritmo Varimax, comunalidades associadas, autovalores, variância unitária e acumulada das variáveis fisicas, quimicas e biológicas significativas para a bacia com campo e pecuária extensiva (LC).

\begin{tabular}{|c|c|c|c|c|c|c|}
\hline Variables & VF1 & VF2 & VF3 & VF4 & VF5 & Commonalities \\
\hline $\mathrm{Mg}^{2+}$ & 0.94 & 0.17 & 0.04 & 0.09 & 0.00 & 0.93 \\
\hline $\mathrm{Ca}^{2+}$ & 0.88 & 0.19 & 0.26 & -0.01 & 0.12 & 0.94 \\
\hline Alcalinity & 0.86 & -0.16 & 0.09 & -0.20 & -0.06 & 0.96 \\
\hline Electrical Cond. & 0.76 & 0.50 & 0.15 & -0.15 & 0.30 & 0.97 \\
\hline $\mathrm{BOD}_{5}$ & 0.30 & 0.78 & 0.08 & -0.16 & 0.15 & 0.83 \\
\hline Total Coliforms & 0.11 & 0.76 & 0.14 & -0.21 & 0.21 & 0.82 \\
\hline Escherichia coli & -0.13 & 0.73 & 0.49 & -0.12 & -0.17 & 0.92 \\
\hline $\mathrm{K}^{+}$ & 0.52 & 0.66 & -0.03 & 0.00 & 0.39 & 0.95 \\
\hline Turbidity & 0.24 & 0.26 & 0.89 & 0.05 & -0.09 & 0.96 \\
\hline Suspended solids & 0.29 & 0.02 & 0.63 & -0.22 & 0.47 & 0.91 \\
\hline $\mathrm{pH}^{\mathrm{T}}$ & 0.15 & -0.22 & 0.10 & 0.91 & -0.07 & 0.95 \\
\hline Flow & -0.47 & -0.11 & -0.24 & 0.78 & -0.19 & 0.94 \\
\hline Dissolved Solids & 0.05 & 0.21 & -0.04 & -0.15 & 0.92 & 0.96 \\
\hline Temperature & -0.03 & -0.04 & 0.21 & -0.06 & 0.06 & 0.95 \\
\hline Precipitation & -0.05 & -0.18 & -0.16 & 0.06 & -0.24 & 0.99 \\
\hline Eigenvalues & 5.90 & 2.30 & 1.79 & 1.41 & 1.14 & \\
\hline Unitary Variance $(\%)$ & 39.32 & 15.34 & 11.94 & 9.39 & 7.62 & \\
\hline Culumative Variance (\%) & 39.32 & 54.65 & 66.59 & 75.98 & 83.60 & \\
\hline
\end{tabular}

Table 3 - Factors of rotated components (VF) by Varimax algorithm, associated commonalities, eigenvalues, unitary and cumulative variance of physical, chemical and biological variables significant for the eucalyptus silviculture catchment (SC).

Tabela 3 - Fatores das componentes rotacionadas (VF) pelo algoritmo Varimax, comunalidades associadas, autovalores, variância unitária e acumulada das variáveis fisicas, químicas e biológicas significativas para a bacia com atividade de silvicultura do eucalipto (SC).

\begin{tabular}{|c|c|c|c|c|c|}
\hline Variables & VF1 & VF2 & VF3 & VF4 & Commonalities \\
\hline Dissolved Solids & 0.95 & 0.10 & 0.04 & 0.09 & 0.94 \\
\hline Flow & -0.93 & -0.11 & -0.01 & 0.14 & 0.92 \\
\hline Alcalinity & 0.92 & 0.07 & 0.16 & -0.07 & 0.99 \\
\hline $\mathrm{Mg}^{2+}$ & 0.90 & 0.12 & 0.18 & -0.02 & 0.99 \\
\hline Electrical Condutivity & 0.90 & 0.10 & 0.13 & -0.03 & 0.99 \\
\hline $\mathrm{pH}$ & 0.88 & 0.09 & -0.15 & -0.16 & 0.89 \\
\hline Turbidity & -0.84 & 0.02 & 0.07 & -0.17 & 0.94 \\
\hline $\mathrm{Ca}^{2+}$ & 0.75 & 0.22 & 0.29 & 0.15 & 0.92 \\
\hline $\mathrm{Cl}^{-}$ & 0.31 & 0.84 & -0.35 & 0.01 & 0.99 \\
\hline $\mathrm{K}^{+}$ & 0.34 & 0.82 & 0.16 & 0.13 & 0.96 \\
\hline $\mathrm{SO}_{4}^{-}$ & -0.54 & 0.66 & -0.43 & 0.03 & 0.97 \\
\hline Temperature & 0.16 & -0.27 & 0.90 & 0.03 & 0.94 \\
\hline Escherichia coli & -0.09 & 0.19 & 0.64 & 0.64 & 0.93 \\
\hline Total Coliforms & -0.01 & 0.03 & 0.02 & 0.97 & 0.96 \\
\hline $\mathrm{BOD}_{5,20}$ & 0.55 & -0.04 & -0.06 & 0.04 & 0.97 \\
\hline Suspended Solids & -0.21 & -0.31 & 0.05 & 0.13 & 0.99 \\
\hline Precipitation & -0.53 & -0.15 & 0.09 & 0.12 & 0.95 \\
\hline Eigenvalues & 8.74 & 2.65 & 1.95 & 1.13 & \\
\hline Unitary Variance (\%) & 51.43 & 15.61 & 11.45 & 6.64 & \\
\hline Cumulative Variance (\%) & 51.43 & 67.04 & 78.49 & 85.12 & \\
\hline
\end{tabular}

Revista Árvore, Viçosa-MG, v.39, n.6, p.1135-1145, 2015 
Vanzella (2004) has also observed an increase of EC with low flow levels, consequence of an increased concentration of dissolved salts. Ribeiro (2009) complements that the EC is sensitive to variations in dissolved solids, especially minerals. The degree to which the salts are dissociated into ions, the charge on each ion and mobility, all interfere with the EC values.

Also for VF1 (SC), it is believed that the variables $\mathrm{pH}$, turbidity and dissolved solids (high and positive loadings) are related to the accumulation of organic matter within the riverbed, due to the low flow levels observed during the monitoring, evidenced by the high negative loadings of the flow. The higher $\mathrm{pH}$ values in the SC (Table 1) may be related to higher concentrations of bicarbonates, especially calcium and magnesium (LIBÂNIO, 2008).

The process was also observed by the authors Formigoni et al. (2011) and Rodrigues and Pissara (2007). Another possibility would be on account of the base flow contribution ( LIKENS et al., 1967; ARCOVA et al., 1985) a hydrological partition responsible for maintaining the water flow when in periods of low rainfall.

The VF4 (LC) is composed by the variables $\mathrm{pH}$ $(0.91)$ and flow rate $(0.77)$, a positive relation was found between the variables which differs from what was observed for SC (Table 3), that is, in $\mathrm{LC}$ the $\mathrm{pH}$ increases as the flow increases. The may be related to the presence of extensive livestock waste that through decomposition of organic material provide conditions for the reduction of the pH (Table 1), as noted by Mosca (2008), so VF4 may be characterized as an "anthropic" factor. Messias (2008) states that the $\mathrm{pH}$ can be considered one of the most important and complex environmental variables to interpret, due to the numerous factors that influence the environment, and such complexity is related to diffuse sources of pollution.

In the catchment with extensive livestock and pasture, VF2 (Table 2) showed high and positive loadings for total coliforms, Escherichia coli, $\mathrm{BOD}_{5.20}$ and potassium. Thus, characterized as a "diffuse pollution" factor due to the impact caused by cattle waste from extensive livestock farming, which was observed by Nonato et al. (2007), Alves et al. (2012) and Bertossi et al. (2013). Lubenow et al. (2012) reported total coliforms and Escherichia coli values equal to 18000 and 100 MPN/ $100 \mathrm{ml}$, respectively, in agricultural areas with little riparian protection. Escherichia coli acts as an indicator of the presence of fecal contamination in the water and $\mathrm{BOD}_{5.20}$ acts as an important parameter to evaluate the degree of organic matter pollution within the water body (von SPERLING, 2005).

Similar factorial Characteristic could be observed for VF3-SC, higher numbers for loads of temperature variables (0.90) and Escherichia coli (0.63), although the values are lower than the ones observed for LC (Table 1). According to Arcova et al. (1993), solar radiation is considered the main variable that controls the water temperature in the streams. In the present study, due to the fact that the area has riparian protection and the observed values were lower than those observed in $\mathrm{LC}$, we is believed that the lack of rainfall may have contributed to the increased loading, as well as the possible concentration of decomposed organic material in the environment, thus, the factor is referred to as "nutrition".

The VF4-SC had higher loads for total coliforms variables (0.96) and Escherichia coli (0.64), Escherichia coli values comes mainly from feces of wild animals, such as hares, deer or graxains (Lycalopex gymnocercus) that roam in the study area. However, high levels of Escherichia coli were observed from January to March 2012, which may be related cattle invasion from neighboring areas, as noted in the study area. This, is due to the expansion of the eucalyptus farming area (5,600 ha) and because of the fragile fences that separate the study area from neighboring cattle farms, which means that cattle from neighboring areas may have had access to the area, and it may take up to two months to find a lost cow/calf when in the woods.

For the catchment with eucalyptus silviculture (Table 3) VF2 was represented by the variables potassium, chloride and sulfate (loads greater than 0.6). These variables are characterized as "mineral" factor based on the considerations of CETESB (2009) and Camara et al. (2006).

According to CETESB (2009) and Von Sperling (2005), chloride and sulfate are found in groundwater, arising from water percolating through soil and rock. The potassium can be found in low concentrations in natural waters (below $10 \mathrm{mg} \mathrm{L}^{-1}$ ) values below this limit were found in this study, as presented in Table 1 . Another source refers to potassium salts used in the industry and agricultural fertilizers (CAMARA et al., 2006), which may be related to fertilizer application

Revista Árvore, Viçosa-MG, v.39, n.6, p.1135-1145, 2015 
(SC). However, there is not enough information to sustain this hypothesis. Also loadings higher than 0.6 were observed for potassium VF2 - LC (Table 2), area in which there was no fertilizer application.

In LC, VF3 presents the highest loadings for suspended solids (0.62) and turbidity (0.89), hence characterizing the factor as "solid", was also verified by Andrade et al. (2007a). The solids loading possibly has its origin in the runoff from the area pasture and livestock activity, as the riparian protection (field and/ or forest) in the area is virtually absent, and the cattle have direct access to the drainage network. The last factor found in LC (VF5) was characterized solely by the dissolved solids variable and can be referred to as an "organic" factor, since the high loadings for this variable may reflect basically the contribution of livestock waste to the water course, either directly or diffusely through runoff.

\section{CONCLUSION}

According to the results and previous observations, the technique of factorial analysis / principal component analysis enabled the selection of four quality-indicator factors of surface water in the basin with the eucalyptus silviculture, which explain $85.12 \%$ of the total variance. Changes in water quality were defined by the following factors: soluble salts, mineral, nutritional and diffuse pollution.

In the catchment with pasture and extensive livestock farming, there were five factors, which together represented $83.5 \%$ of the variance, namely: soluble salts, diffuse pollution (waste from extensive livestock farming), solids (representing the processes of erosion and runoff), anthropic (influence from diffuse sources of pollution) and organic (dissolved solids).

The groups of the factors that best characterized the surface water with the studied areas demonstrated that the replacement of pasture and extensive livestock rearing with eucalyptus forests attenuated diffuse pollution (Escherichia coli) in the area and generally did not result in major changes in the physicochemical and biological characteristics of water.

Factorial analysis did not cause significant reduction in the number of variables for this study, as the best model fit occurred with the inclusion of 15 of the 18 variables in LC and 17 of the 18 variables in SC.

\section{ACKNOWLEDGMENTS}

We would like to thank everyone who contributed to this study, CNPq, CAPES, FINEP, FAPERGS, Federal University of Santa Maria; the GERHI group; STORA ENSO and Mr. Jose Ildo Spanevello, of the San Carlos farm, where part of this study was carried out.

\section{REFERENCES}

\section{ASSOCIAÇÃO BRASILEIRA DE NORMAS} TÉCNICAS - ABNT. NBR 9898 Preservação e técnicas de amostragem de efluentes líquidos e corpos receptores. 1987. 22p.

APHA; AWWA; WPCF. Standard methods for the examination of water and wastewater. 20.ed. Washington D.C.: 1998.

ALVARES, C.A.; STAPE, J.L.; SENTELHAS, P.C.; GONÇALVES, J.L.M.; SPAROVEK, G. Köppen's climate classification map for Brazil.

Meteorologische Zeitschrift, v.22, p.711728,2013

ALVES, I. C.C.; EL-ROBRINI, M.; SANTOS, M.L.S.; MONTEIRO, S.M.; BARBOSA, L.P.F.; GUIMARÃES, J.T.F. Qualidade das águas superficiais e avaliação do estado trófico do Rio Arari (Ilha de Marajó, norte do Brasil). Acta

Amazonica, v.42, n.1, p.115-124, 2012.

ANDRADE, E.M.; ARAÚJO, L.F.P.; ROSA, M.F.; DISNEY, W.; ALVES, A.B. Seleção dos

indicadores da qualidade das águas superficiais pelo emprego da análise multivariada. Revista Engenharia Agrícola, v.27, n.3, p.683-690, 2007a.

ANDRADE, E.M.; ARAÚJO, L.F.P.; ROSA, M.F.; GOMES, R.B.; LOBATO, F.A.O. Fatores determinantes da qualidade das águas superficiais na bacia do Alto Acaraú, Ceará, Brasil. Ciência Rural, v.37, n.6, p.1791-1797, 2007b.

ARCOVA, F.C.S.; CICCO, V.; LIMA, W.P. Balanço dos nutrientes $\mathrm{Ca}^{+2}, \mathrm{Mg}^{+2}, \mathrm{Na}^{+1}, \mathrm{~K}^{+1} \mathrm{e} \mathrm{NO}_{3}^{-1}$ em bacia hidrográfica experimental com vegetação natural do Parque Estadual da Serra do Mar Núcleo Cunha - SP. IPEF, n.31, p.61-67, 1985. 
ARCOVA, F.C.S.; CESAR, S.F.; CICCO, V. Qualidade da água e dinâmica de nutrientes em bacia hidrográfica recoberta por floresta de mata atlântica. Revista do Instituto Florestal, v.5, n.1, p.1-20, 1993.

BERTOSSI, A.P.A.; CECÍLIO, R.A.; NEVES, M.A.; OLIVEIRA, G. Qualidade da água em microbacias hidrográficas com diferentes coberturas do solo no sul do Espírito Santo. Revista Árvore, v.37, n.1, p.107-117, 2013.

BRASIL. Lei n. 9.433 de 8 de janeiro de 1997. Institui a Política Nacional de Recursos Hídricos. Disponível em: http://www.planalto.gov.br/ ccivil_03/leis/L9433.HTM. Acesso em: 22 fev. 2014.

BRASIL. Lei n. 12.651 de 25 de maio de 2012. Institui o Código Florestal Brasileiro. Diário Oficial [da] República Federativa do Brasil, Brasília, 25 maio 2012. Disponível em: < http://www.planalto.gov.br/ ccivil_03/_Ato2011-2014/2012/Lei/L12651.htm>. Acesso em: 02 mai. 2013.

BRITO, L.T.L.; SILVA, A.S.S.; SRINIVASAN, V.S.; GALVÃO, C.O.; GHEYI, H.R. Uso de análise multivariada na classificação das fontes hídricas subterrâneas da bacia hidrográfica do Salitre. Engenharia Agrícola, v.26, n.1, p.36-44, 2006.

BURIN, R. Variabilidade da qualidade da água e do estado trófico do reservatório do Vacacaí Mirim. 2011. 120f. (Mestrado em Engenharia Civil) Universidade federal de Santa Maria, Santa Maria, 2011.

CÂMARA, C.D.; LIMA, W.P.; ZÁKIA, M.J.B. Critérios e indicadores hidrológicos de monitoramento em microbacias. In: As Florestas Plantadas e a Água... São Carlos: RiMa, 2006. p.107-140.

CAMPELLO, F.D.; BRAGA, F.B.; GONÇALVES, C.V.; GONÇALVES, C.S.; SANTOS JÚNIOR, J.E.; RODRIGUES, G.G.; GUERRA, T.; HARTZ, S.M. Avaliação preliminar da qualidade das águas da Floresta Nacional de São Francisco de Paula, RS, Brasil. Revista Brasileira de Biociências, v.3, n.1/4, p.9-46. 2005.
CETESB - COMPANHIAAMBIENTAL DO ESTADO DE SÃO PAULO. Relatório de Qualidade das Águas Superficiais do Estado de São Paulo. 2009. Disponível em: http://www.cetesb.sp.gov.br/userfiles/file/agua/ aguas-superficiais/variaveis.pdf Acesso em: 23 jul. 2012.

CPRH. Medição de vazão de efluentes líquidos: escoamento livre. 2004. Disponível em: http://www.cprh.pe.gov.br/downloads/normascprh-2004.pdf. Acesso em: set. 2011.

FORMIGONI, Y.; BRITES, A.P.; FERNANDES, C.; PORTO, M. Análise crítica da curva de permanência de qualidade da água com base em dados históricos. In: SIMPÓSIO BRASILEIRO DE RECURSOS HIDRÍCOS, 19., 2011. Disponível em: http:/www.abrh.org.br/SGCv3/UserFiles/ Sumarios/ec99f1061725d63695b7bea3067296d4 _31aef3f050dfe0930e76fff29fa8b397.pdf. Acesso em: 12 dez. 2012.

GARDIMAN JUNIOR, B.S. Qualidade da água de microbacias hidrográficas sob atividades silviculturais em Aracruz, ES. 2012. 123f. Dissertação (Mestre em Ciências Florestais) - Universidade Federal do Espírito Santo, Vitória, 2012.

GATICA, E.A.; ALMEIDA, C.A.; MALLEA, M.A.; DEL CORIGLIANO, M.C.; GONZÁLEZ, P. Water quality assessment, by statistical analysis, on rural and urban areas of Chocancharava River (Río Cuarto), Córdoba, Argentina.

Environmental Monitoring and Assessment, v. 184, p.7257-7274, 2012.

GUEDES, H.A.S.; SILVA, D.D.; ELESBON, A.A.A.; RIBEIRO, C.B.M.; MATOS, A.T.; SOARES, J.H.P. Aplicação da análise estatística multivariada no estudo da qualidade da água do Rio Pomba, MG. Revista Brasileira de Engenharia Agrícola e Ambiental, v.16, n.5, p.558-563, 2012.

HAIR JR., J.F.; BLACK, W.C.; BABIN, B.J.; ANDERSON, R.E.; TATHAM, R.L. Análise multivariada de dados. 5.ed. Porto Alegre: Bookman, 2005. 593p.

IUSS Working Group WRB. World Reference Base for Soil Resources 2014;

Revista Árvore, Viçosa-MG, v.39, n.6, p.1135-1145, 2015 
International soil classification system for naming soils and creating legends for soil maps. Rome: FAO, 2014. (World Soil Resources Reports, 106)

LAUERMANN, A. Caracterização química dos efluentes gerados pelo aterro controlado de Santa Maria e retenção de chumbo e zinco por um argissolo da depressão central do Rio Grande do Sul. 2007. 72f. Dissertação (Mestre em Ciência do Solo) - Universidade federal de Santa Maria, Santa Maria, 2007.

LIAO, S.W.; GAU, H.S.; LAI, W.L.; CHEN, J.J.; LEE, C.G. Identification of pollution of Tapeng Lagoon from neighbouring rivers using multivariate statistical method. Journal of Environmental Management, v.88, p.286292, 2008.

LIKENS, G.E.; BORMANN, F.H.; JOHNSON, N.M.; PIERCE, R.S. The Calcium, Magnesium, Potassium, and Sodium Budgets For a Small Forested Ecosystem. Durham, Ecology, v.48, n.9, p.772-785, 1967.

LIMA, W.P.; ZAKIA, M.J.B. As florestas plantadas e a água: implementando o conceito da microbacia hidrográfica como unidade de planejamento. São Paulo: Rima, 2006. 226 p.

LIBÂNIO, M. Fundamentos de qualidade e tratamento de água. 2. ed. Campinas: Átomo, 2008. 443p.

LUBENOW, A.T.; OLIVEIRA FILHO, P.C.; VIDAL, C.M.S.; CAVALLINI, G.S.; CARTELE, Y.C. Impacto do uso e ocupação da terra na qualidade da água da bacia hidrográfca do rio Nhapindazal, Irati (PR). Ambiência Guarapuava, v.8, n.3, p.845-858, 2012.

MELO, A.S.; HEPP, L.U. Ferramentas estatísticas para análise de dados provenientes de biomonitoramento. Oecologia Brasiliensis, v.12, n.3,p.463-486, 2008.

MESSIAS, T.G. Influência da toxidade da água e do sedimento dos rios São Joaquim e Ribeirão Claro na bacia do Corumbataí. 2008. 125f. Dissertação (Mestrado em Ciências) - Centro de Energia Nuclear na Agricultura, Universidade de São Paulo, Piracicaba, 2008.
MOSCA, A.A.O. Avaliação dos impactos ambientais de plantações de eucalipto no Cerrado com base na análise comparativa do ciclo hidrológico e da sustentabilidade da paisagem em duas bacias de segunda ordem. 2008. 256f. Tese (Doutorado em ciências) - Universidade de São Paulo, São Paulo, 2008.

NONATO E.A.; VIOLA, Z.G.G.; ALMEIDA, K.C.B.; SCHOR, H.H.R. Tratamento estatístico dos parâmetros da qualidade das águas da bacia do alto curso do Rio das Velhas. Química Nova, v.30, n.4, p.797-804, 2007.

NORUSIS, M.J. SPSS Base System User's Guide. Chicago: SPSS, 1990. 520p.

PEREIRA, J.C.R. Análise de dados qualitativos: estratégias metodológicas para as ciências da saúde, humanas e sociais. São Paulo: Edusp, 2001.

RIBEIRO, K.H. Qualidade da água superficial e a relação com o uso do solo e componentes ambientais na microbacia do rio campestre, Colombo, PR. 2009. 51f. (Mestre em Ciência do Solo) - Universidade Federal do Paraná, Curitiba, 2009.

RODRIGUES, F.M.; PISSARA, T.C.T.; GREGORIO, C.E.B. Qualidade da água de uma microbacia hidrográfica com diferentes usos do solo na região de Taquaritinga, Estado de São Paulo. In: SIMPÓSIO BRASILEIRO DE RECURSOS HÍDRICOS, 17., 2007, São Paulo. p.1-11.

SALGADO, E.V.; ANDRADE, E.M.; FONTENELE, S.B.; MEIRELES, A.C.M. Similaridade das variáveis hidroquímicas com o uso da análise multivariada, na bacia do Salgado, Ceará.

Revista Caatinga, v.24, n.3, p.158-166, 2011.

STRECK, E.V.; KÄMPF, N.; DALMOLIN, R.S.D.; KLAMT, E.; NASCIMENTO, P.C.; SCHNEIDER, P.; GIASSON, E.; PINTO, L.F.S. Solos do Rio Grande do Sul. 2.ed. Porto Alegre: EMATER/ RS, 2008. 222p.

VANZELA, L.S. Qualidade de água para a irrigação na microbacia do córrego três barras no município de Marinópolis, SP. 2004. 91f. Dissertação 
(Mestrado em Agronomia) - Universidade Estadual de São Paulo, Ilha Solteira, 2004.

von SPERLING, M. Princípios do tratamento biológico de águas

residuárias: introdução à qualidade das águas e ao tratamento de esgotos. 3.ed. Belo Horizonte:
UFMG, 2005. v.1.452p.

WANG, X.; CAI, Q.; YE, L.; QU, X. Evaluation of spatial and temporal variation in stream water quality by multivariate statistical techniques: A case study of the Xiangxi River Basin, China. Quaternary International, v.282, N.19, P.137-144, 2012. 
